\title{
Qualities of a Good and Effective Teacher: Slovak EFL Pre-Service and In-Service Teachers' Perspectives
}

\author{
Rastislav Metruk \\ University of Žilina \\ Correspondence concerning this article should be addressed to Rastislav Metruk, Department of English \\ Language and Literature, Faculty of Humanities, University of Žilina, Univerzitná 8215/1, 01026 Žilina, \\ Slovakia.E-mail: rastislav.metruk@fhv.uniza.sk
}

\begin{abstract}
A plethora of researchers have attempted to examine the characteristics of a good and effective teacher in order to enhance the process of teaching foreign languages. In line with those explorations, this study aims at performing a comparison between Slovak pre-service EFL (English as a foreign language) teachers' and Slovak in-service EFL teachers' perceptions of a good and effective language teacher. To achieve this objective, a convenient sample of Slovak university EFL students who were pre-service teachers $(n=74)$ and Slovak lower-secondary and upper-secondary school teachers $(n=63)$ were employed in the study. Using a 57-item Likerttype questionnaire, independent-samples t-tests were conducted to investigate the potential differences between the perceptions of the pre-service teachers and in-service teachers. Moreover, the 10 highest-mean and 10 lowest-mean items of both groups were analyzed. The research results revealed that statistically significant differences $(p \leqslant 0.05)$ were detected in only 12 of the 57 items. Furthermore, a closer examination of the differences and the items with the highest and lowest means indicated that the pre-service teacher participants favored traditional teaching more than their in-service teacher counterparts, who preferred CLT (Communicative Language Teaching) to a greater extent. The potential implications of these findings indicate that the fundamental principles of CLT such as employing plenty of pair-work and group-work activities, facilitating learners' autonomy and responsibility for their own learning, or varying classroom interaction strategies deserve more careful attention during pre-service teacher training.
\end{abstract}

Keywords: good and effective language teacher, pre-service teacher, in-service teacher, EFL learner, Communicative Language Teaching, traditional teaching

\section{Introduction}

Learning a foreign language is undoubtedly a complex process as one has to master both language skills and systems (Hundarenko, 2019; Hojatpanah \& Dashtestani, 2020; Kapranov, 2020; Lacková, 2019; Leláková \& Šavelová, 2020; Putrawan, 2019; Stognieva, 2019; Todaka, 2020) in order to become an effective language user. Moreover, language conveys knowledge as well as cultural data and it mirrors the important and specific thoughts of individuals (Namaziandost, Sabzevari \& Hashemifardnia, 2018). Therefore, being a good and effective language teacher is not an easy task and one has to display a number of characteristics in order to become a successful instructor. Al-Mahrooqi, Denman, Al-Siyabi, and Al-Maamari (2015) maintain that possessing knowledge of these features enables instructors to enhance their pedagogical practices by allowing them to improve their positive characteristics. Moreover, teachers are allowed to find ways to overcome those features that are less valued or regarded as inappropriate in a specific teaching/learning context, hence the need for further investigation in this area.

Although it is typically the position of a facilitator that language teachers hold (and despite the fact that recently, the teacher-centered learning model has shifted towards a learner-centered learning model [Namaziandost et al., 2019]), foreign language instructors occupy an instrumental role when it comes to effective language learning and teaching. "Considering the degree of the teacher's influence, it is important to understand what teachers should do to promote positive results in the lives of students - with regard to school achievement, positive attitudes toward school, interest in learning, and other desirable outcomes" (Stronge, 
2018, p. 3-4). Moreover, this day and age places high demands on instructors due to the fact that modern technologies have heavily influenced all parts of human society, including education. Examining the qualities of a good and effective teacher, as perceived by both pre-service teachers and in-service teachers, can be, therefore, potentially beneficial to researchers, instructors, and students themselves. Furthermore, it should be emphasized that the possible mismatches between the perceptions of students and teachers may negatively influence students' satisfaction with the language class and could have a negative impact on their ultimate achievement (Alimorad \& Tajgozari, 2016).

Teachers' effectiveness and quality of teaching has been of considerable interest to researchers and scholars for quite some time, largely concentrating on the specific traits and behaviors that are believed to constitute successful teaching (Çelik, Arikan, \& Caner, 2013). Some scholars tried to analyze teacher effectiveness from the standpoint of students, others from the teachers' viewpoint, and some attempted to examine this issue by uncovering the differences between the perceptions of the two groups (Alimorad \& Tajgozari, 2016). However, in the context of Slovak EFL teaching and learning, such research seems to be absent; thus, this study attempts to fill in the gap and shed more light on characteristics of good and effective EFL teachers in the Slovak context. Moreover, the teacher-centered approach has shifted towards the learner-centered way of teaching, but upfront teaching still seems to exist to a certain degree in a number of countries, including Slovakia. The outcomes of this research could then be utilized to point out which characteristics of the traditional teaching approaches still appear to be prevalent within the context of Slovak EFL teaching from the pre-service and in-service teachers' standpoints. Additionally, the research results may be evaluated and compared with other studies performed in different countries, which could contribute towards the existing knowledge of effective EFL teachers, a concept that can be regarded as an endless attempt within the unstable and dynamic field of teaching English.

\section{Background Literature}

Foreign language teachers and students may have either similar or different opinions on effective language teaching, and the intersection of the two concepts has ramifications for language learning and teaching effectiveness (Moradi \& Sabeti, 2014). The notion of a good teacher has been examined from several standpoints over the past several decades, but it should be noted that most of the explorations have been carried out in the Western contexts with a tendency to analyze teachers across disciplines (Zhang \& Watkins, 2007). Several studies, however, have been undertaken in the non-Western contexts, including the Middle East nations such as the United Arab Emirates, Saudi Arabia, Yemen, Oman, or Iran. The literature offers various significant findings regarding the features related to effective EFL teaching and learning (Al-Mahrooqi, Denman, Al-Siyabi, and Al-Maamari, 2015).

Numerous studies examining the characteristics of good and effective EFL teacher from the standpoint of a learner have been conducted to date (e.g., Barnes, 2013; Çakmak and Gündüz, 2018; Delaney, Johnson, Johnson, \& Treslan, 2010; Demiroz \& Yesilyurt, 2015; Febriyanti, 2018; Ghasemi \& Hashemi, 2011; Javid, 2014; Kourieos \& Evripidou, 2013; Lee, 2010; Mutlu \& Özkan, 2017; Sabbah, 2018; Sandholtz, 2011; Zadeh, 2016).

For instance, the study by Demiroz and Yesilyurt (2015) aimed at examining how prospective English teachers at two English language departments in Turkey (Department of English Language Teaching and Department of English Language and Literature) perceive effective foreign language teachers. The findings indicated that statistically significant differences exist between the two groups in favor of the English language teaching department.

Sandholtz (2011) examined the descriptions of effective and ineffective teaching experiences provided by preservice teachers at a public university in California, which led to four interrelated conclusions. First, when describing their effective and ineffective experiences, most of the pre-service teachers were not focused on management, but rather on instructional practices. Second, the subjects seemed to be developing their personal capacity and inclination towards issues in relation to understanding. According to Stanholtz (2011), "They mentioned student understanding more frequently when describing ineffective instruction rather than effective instruction, suggesting an inclination to recognize signs of students' misunderstanding" (p. 42-43). 
Third, they determined alternate approaches to reduce students' confusion and improve their understanding. Finally, the pre-service teachers did not demonstrate the in-depth reasoning of accomplished teachers; the candidates displayed the potential to critically explore their practice and sharpen their judgement.

Other study conducted by Çelik, Arikan, and Caner (2013) surveyed 998 undergraduate students at a state university at Turkey regarding successful English language teachers. Based on the survey, an effective language teachers can be someone who exhibits fairness in decision-making, is successful in reducing students' anxiety, demonstrates enthusiasm, teaches pronunciation well, teaches speaking skills adequately, has a sound knowledge of vocabulary, teaches reading skills adequately, has sound knowledge of grammar, is adept at providing explanations in Turkish (mother tongue), is good at classroom management, and teaches writing skills adequately.

Kourieos and Evripidou (2013) also sought to identify the characteristics that are assigned to effective EFL teachers as perceived by Cypriot university students. On the basis of the participants' responses, an effective EFL teacher no longer has a directive and authoritarian personality, but apart from other characteristics, an instructor is an individual who takes into account their students' individual differences, anxiety, interests, and abilities.

On the other hand, there are also a number of studies that were focused on revealing the differences between the perceptions of students and teachers in terms of effective language teachers. For instance, Alimorad and Tajgozari (2016) compared the views of high school students and instructors on effective teachers in different cities in Iran. It was found that the perceptions of students differed dramatically from those of their teacher counterparts. The instructors preferred a more traditional approach, while the students tended to favor the communicative approach. Furthermore, different perceptions between males and females were also detected.

In a similar way, the results of the study performed by Park and Lee (2006) indicated that on the whole, the opinions on effective language teachers as perceived by instructors were significantly different from those of the Korean high school students in all three categories (English proficiency, pedagogical knowledge, and socioaffective skills). The teachers regarded English proficiency the highest while the students considered pedagogical knowledge to be the most important.

According to Brown (2009), whose study attempted to identify and compare teachers' and students' ideals of effective teacher behavior at the University of Arizona, the students appeared to favor a grammar-based approach, while their teacher counterparts seemed to prefer a more communicative classroom, which was supported by the detection of significant differences in areas such as target language use, error correction, or group work. Other studies that demonstrated that statistically significant differences exist between the university students' and teachers' perceptions of effective EFL teachers include Katooli and AbdolmanafiRokni (2015), Ramazani (2014), and Tok (2010).

On the other hand, the study by Al-Mahrooqi, Denman, Al-Siyabi, and Al-Maamari (2015), which aimed at exploring this issue in the Arab Gulf, produced different outcomes. The yielded results suggest that Omani students and teachers generally agree about the significance of all characteristic categories, assigning special importance to the categories of English language proficiency and treating students equally. Another study by Alzobiani (2020), which examined the extent to which students' and teachers' perceptions differ, also indicated that there was no statistically significant difference in the perceptions of Saudi EFL students and teachers regarding the characteristics of effective teachers. The quantitative analysis of the results in the study conducted by Shishavan and Sadeghi (2009) also showed that the responses of students (university, high school, and language institute students) differed from those of the teachers in only eight instances out of the 46 items in the questionnaire on the perception of an effective English language teacher.

Apparently, further examination in this area, especially in countries where such investigation is yet to be conducted, is necessary as the differences (whether subtle or broad) in perceptions of good and effective teachers play a substantial role in either improving or hampering the process of language learning. Thus, this study attempts to perform a comparison between the perceptions of the Slovak pre-service and in-service teachers regarding good and effective EFL instructors. 
In order to achieve the research aim, the following research questions were formulated:

1. What are the most important and the least important characteristics of a good and effective EFL teacher according to Slovak pre-service teachers?

2. What are the most important and the least important characteristics of a good and effective EFL teacher according to Slovak in-service teachers?

3. How are Slovak pre-service teachers' opinions and attitudes towards a good and effective teacher different from those of Slovak in-service teachers?

\section{Materials and Methods}

\section{Research background}

The notion of good and effective language teaching as perceived by both Slovak pre-service and in-service teachers was the primary focus of this research. The employed research instrument was the questionnaire, which was distributed to both groups of participants. Afterwards, the obtained data were statistically analyzed, the results interpreted, and conclusions drawn.

\section{Participants}

The participants of this study were formed by two groups: Slovak university EFL learners studying in the Teaching English as a Foreign Language program at a Slovak university - the pre-service teachers, and Slovak lower-secondary and upper-secondary teachers - the in-service teachers.

The pre-service teachers comprised a total of 74 learners, 56 males and 18 females. On average, they were 21.5 years of age, all of them holding Slovak nationality and residing in Slovakia. The average number of years they had been studying English was 12.9 and their level of English was between B2 and C1.

The total amount of in-service teachers participating in this study was 63, four males and 59 females. The average age was 37.5 years and their qualification distribution was six novice teachers, 16 independent teachers, 20 teachers with the first attestation, and 21 teachers with the second attestation. Looking at the type of school they taught at, 29 of them worked as teachers at lower-secondary schools and 34 of them were employed as upper-secondary teachers.

\section{Instrument and Procedures}

The research method employed in order to gather the necessary data was a 57-item Likert-type questionnaire. A Likert scale (named after Rensis Likert who was the first person to use a scale with restricted number of points in order to measure the level of agreement) is the most common form of a restricted interval scale item (Privitera \& Ahlgrim-Delzell, 2019). The instrument, which was developed by the author after a rigorous review of the literature on the qualities of good and effective teachers, is a modified version of existing questionnaires on teacher effectiveness and perceptions of good teacher characteristics by Al-Mahrooqi, Denman, and AlSiyabi (2015), Moradi and Sabeti (2014), and Shishavan and Sadeghi (2009). The questionnaire was revised and modified three times with the help of the author's peers and colleagues. The final version of the instrument comprised 57 items concerning the qualities of a good and effective teacher. Using the Cronbach's alpha formula, the internal consistency (questionnaire reliability coefficient) was calculated at 0.94 , which can be regarded as high for the purposes of this study.

The questionnaire was distributed via Google Forms to both groups. The participants were required to indicate the importance of items by selecting the best choice out of the four options $(1=$ unimportant quality of a good and effective teacher, 2 = slightly important quality of a good and effective teacher, 3 = moderately important quality of a good and effective teacher, 4 = very important quality of a good and effective teacher). For example: 


\section{RASTISLAV METRUK}

\section{A good and effective EFL teacher is someone who should:}

Be well prepared for each lesson.

Be able to provide clear instructions for tasks.

Be able to present content to students in a meaningful way.
1

1

1
3

3

3
4
4
4

The subjects were reassured that there were no right or wrong answers, just those that were right for them so as to examine their perceptions of good and effective teaching.

\section{Data Analysis}

In order to perform the comparison between the pre-service teachers' and in-service teachers' perceptions of a good and effective teacher, 57 independent-samples $t$ tests (between the perceptions of pre-service teachers and in-service teachers) were carried out. Auerbach and Zeitlin (2014) maintain that the $p$ value in social sciences is typically set at $0.05(p \leqslant 0.05)$. This means that those questionnaire items whose $p$ value equaled or was lower than 0.05 were deemed statistically significant in this study. The items are statistically analyzed in the results section.

\section{Results}

In order to examine the perceptions of both groups of participants more carefully, the ten highest-mean and lowest-mean qualities of a good and effective EFL teacher were extracted.

Table 1 shows that six items that received the highest means in both groups of participants were the same (items $2,3,25,33,35$, and 37). Only one of the five characteristics is connected to the level of communicative ability, and that is item 33 "have good communication skills". Another two items that both groups regarded as the most important were "be able to present content to students in a meaningful way" and "be able to provide clear instructions for the task". These two qualities represent the basic competences every language teacher needs to have. The last two items that were shared were "being fair and correct (with feedback, giving turns, attending to individual differences)" and "be polite and respect the personality of students".

The pre-service teachers added other items to the list of the most important characteristics of a good and effective teacher, most of them being unrelated to the communicative ability of a teacher: "arouse students' motivation for learning English", "be helpful to students inside and outside the classroom", and "build a positive relationship with students but focus on retaining a professional distance". The final item, which was somehow connected with the language competence of a teacher, was "speak audibly and clearly".

The in-service teachers, on the other hand, added some items also directly related to actual teaching: "provide opportunities to use English through meaningful tasks and activities", "be creative; use various methods and techniques in teaching", "be knowledgeable (have both subject matter knowledge and pedagogical knowledge)", the last one also being connected to the language competence of a good and effective teacher. The last item for the teachers, similar to the student-added items, was mainly connected with the nature of classroom relationships (how a good and effective teacher should approach their learners): "show interest in students (e.g. by remembering their names, etc.) and their learning".

Table 2 (items with the lowest means) displays an even greater degree of similarity since seven of the ten items were the same for both groups (items $5,10,29,41,42,43$, and 44). Two of the items are connected to actual teaching: "give a reasonable amount of homework/home assignments" and "be aware of current teaching techniques". The other two items are related to teachers' qualifications and experience: "have more than five years of experience teaching English" and "have a university degree in teaching". The remaining items can be regarded as unrelated to "direct teaching": "be familiar with the social and cultural backgrounds of learners", "be neat and tidy in appearance", and "know English culture well". 


\section{QUALITIES OF A GOOD AND EFFECTIVE TEACHER}

Table 1

Questionnaire Items with the Highest Means for Students and Teachers

\begin{tabular}{|c|c|c|c|c|c|}
\hline \multicolumn{3}{|c|}{ Pre-service Teachers } & \multicolumn{3}{|c|}{ In-service Teachers } \\
\hline $\begin{array}{c}\text { Item } \\
\text { no. }\end{array}$ & Item & Mean & Item no. & Item & Mean \\
\hline 3 & $\begin{array}{l}\text { Be able to present content to students in a } \\
\text { meaningful way. }\end{array}$ & 3.81 & 2 & $\begin{array}{l}\text { Be able to provide clear instructions for } \\
\text { tasks. }\end{array}$ & 3.87 \\
\hline 2 & $\begin{array}{l}\text { Be able to provide clear instructions for } \\
\text { tasks. }\end{array}$ & 3.80 & 3 & $\begin{array}{l}\text { Be able to present content to students in a } \\
\text { meaningful way. }\end{array}$ & 3.86 \\
\hline 25 & $\begin{array}{l}\text { Be fair and correct (with feedback, giving } \\
\text { turns, attending to individual differences). }\end{array}$ & 3.80 & 25 & $\begin{array}{l}\text { Be fair and correct (with feedback, giving } \\
\text { turns, attending to individual differences). }\end{array}$ & 3.86 \\
\hline 50 & Speak audibly and clearly. & 3.78 & 33 & Have good communication skills. & 3.84 \\
\hline 37 & $\begin{array}{l}\text { Be polite and respect the personality of } \\
\text { students. }\end{array}$ & 3.76 & 6 & $\begin{array}{l}\text { Provide opportunities to use English } \\
\text { through meaningful tasks and activities. }\end{array}$ & 3.78 \\
\hline 16 & $\begin{array}{l}\text { Arouse students' motivation for learning } \\
\text { English. }\end{array}$ & 3.65 & 35 & $\begin{array}{l}\text { Be patient (allow for students' questions, } \\
\text { comments, and participation). }\end{array}$ & 3.76 \\
\hline 33 & Have good communication skills. & 3.65 & 32 & $\begin{array}{l}\text { Show interest in students (e.g. by } \\
\text { remembering their names, etc.) and their } \\
\text { learning. }\end{array}$ & 3.75 \\
\hline 22 & $\begin{array}{l}\text { Be helpful to students inside and outside } \\
\text { the classroom. }\end{array}$ & 3.62 & 37 & $\begin{array}{l}\text { Be polite and respect the personality of } \\
\text { students. }\end{array}$ & 3.73 \\
\hline 35 & $\begin{array}{l}\text { Be patient (allow for students' questions, } \\
\text { comments, and participation). }\end{array}$ & 3.62 & 19 & $\begin{array}{l}\text { Be creative; use various methods and } \\
\text { techniques in teaching. }\end{array}$ & 3.73 \\
\hline 36 & $\begin{array}{l}\text { Build a positive relationship with students } \\
\text { but focus on retaining a professional } \\
\text { distance. }\end{array}$ & 3.62 & 27 & $\begin{array}{l}\text { Be knowledgeable (have both subject } \\
\text { matter knowledge and } \\
\text { pedagogical knowledge). }\end{array}$ & 3.7 \\
\hline
\end{tabular}

Table 2

Questionnaire Items with the Lowest Means for Students and Teachers

\begin{tabular}{|c|c|c|c|c|c|}
\hline \multicolumn{3}{|c|}{ Pre-service Teachers } & \multicolumn{3}{|c|}{ In-service Teachers } \\
\hline $\begin{array}{c}\text { Item } \\
\text { no. }\end{array}$ & Item & Mean & Item no. & Item & Mean \\
\hline 42 & $\begin{array}{l}\text { Have more than five years of experience } \\
\text { teaching English. }\end{array}$ & 2.28 & 42 & $\begin{array}{l}\text { Have more than five years of experience } \\
\text { teaching English. }\end{array}$ & 2.35 \\
\hline 43 & $\begin{array}{l}\text { Be familiar with the social and cultural } \\
\text { backgrounds of learners. }\end{array}$ & 2.61 & 43 & $\begin{array}{l}\text { Be familiar with the social and cultural } \\
\text { backgrounds of learners. }\end{array}$ & 2.89 \\
\hline 29 & Be neat and tidy in appearance. & 2.68 & 5 & $\begin{array}{l}\text { Give a reasonable amount of homework/ } \\
\text { home assignments. }\end{array}$ & 2.98 \\
\hline 14 & $\begin{array}{l}\text { Employ plenty of pair work and group } \\
\text { work in which his/her learners can practice } \\
\text { English. }\end{array}$ & 2.91 & 41 & $\begin{array}{l}\text { Have a university degree in Teaching } \\
\text { English as a Foreign Language. }\end{array}$ & 3.08 \\
\hline 10 & Know English culture well. & 2.93 & 29 & Be neat and tidy in appearance. & 3.10 \\
\hline 23 & $\begin{array}{l}\text { Support the notion that fluency is } \\
\text { somewhat more important than accuracy. }\end{array}$ & 2.95 & 10 & Know English culture well. & 3.13 \\
\hline 48 & $\begin{array}{l}\text { Vary class interaction strategies (e.g. use } \\
\text { group and pair work, drama, role-plays, } \\
\text { debates, etc.). }\end{array}$ & 2.95 & 17 & Diagnose learners' learning problems. & 3.17 \\
\hline 5 & $\begin{array}{l}\text { Give a reasonable amount of homework/ } \\
\text { home assignments. }\end{array}$ & 3.01 & 44 & Be aware of current teaching techniques. & 3.19 \\
\hline 41 & $\begin{array}{l}\text { Have a university degree in Teaching } \\
\text { English as a Foreign Language. }\end{array}$ & 3.01 & 8 & $\begin{array}{l}\text { Be up-to-date (e.g. use the Internet and } \\
\text { recent technologies in teaching). }\end{array}$ & 3.25 \\
\hline 44 & Be aware of current teaching techniques. & 3.03 & 11 & $\begin{array}{l}\text { Teach English in English - use as little L1 } \\
\text { (mother tongue) as possible. }\end{array}$ & 3.27 \\
\hline
\end{tabular}

Other items marked as the least important by the pre-service teachers were directly connected with some of the basic principles of communicative language teaching (CLT): "employ plenty of pair work and group work in 
which his/her learners can practice English", "support the notion that fluency is somewhat more important than accuracy.", and "vary class interaction strategies (e.g. use group and pair work, drama, role-plays, debates, etc.)".

The in-service teachers' remaining items that were marked as the least important were "diagnose learners' learning problems", "be up-to-date (e.g. use the Internet and recent technologies in teaching).", and "Teach English in English - use as little L1 (mother tongue) as possible", the two last items being directly related with actual teaching.

In order to investigate whether statistically significant differences existed between the two groups, 57 independent-samples t-tests were run. The table that includes all the items can be found in the appendix. All mean values of both pre-service teachers and in-service teachers along with standard deviations are illustrated in Figures 1 and 2 . The items that indicate the statistically significant difference $(p \leqslant 0.05)$ between the preservice teachers' and in-service teachers' perceptions are shown in Table 3.

\section{Figure 1}

Means and Standard Deviations for Items 1-28

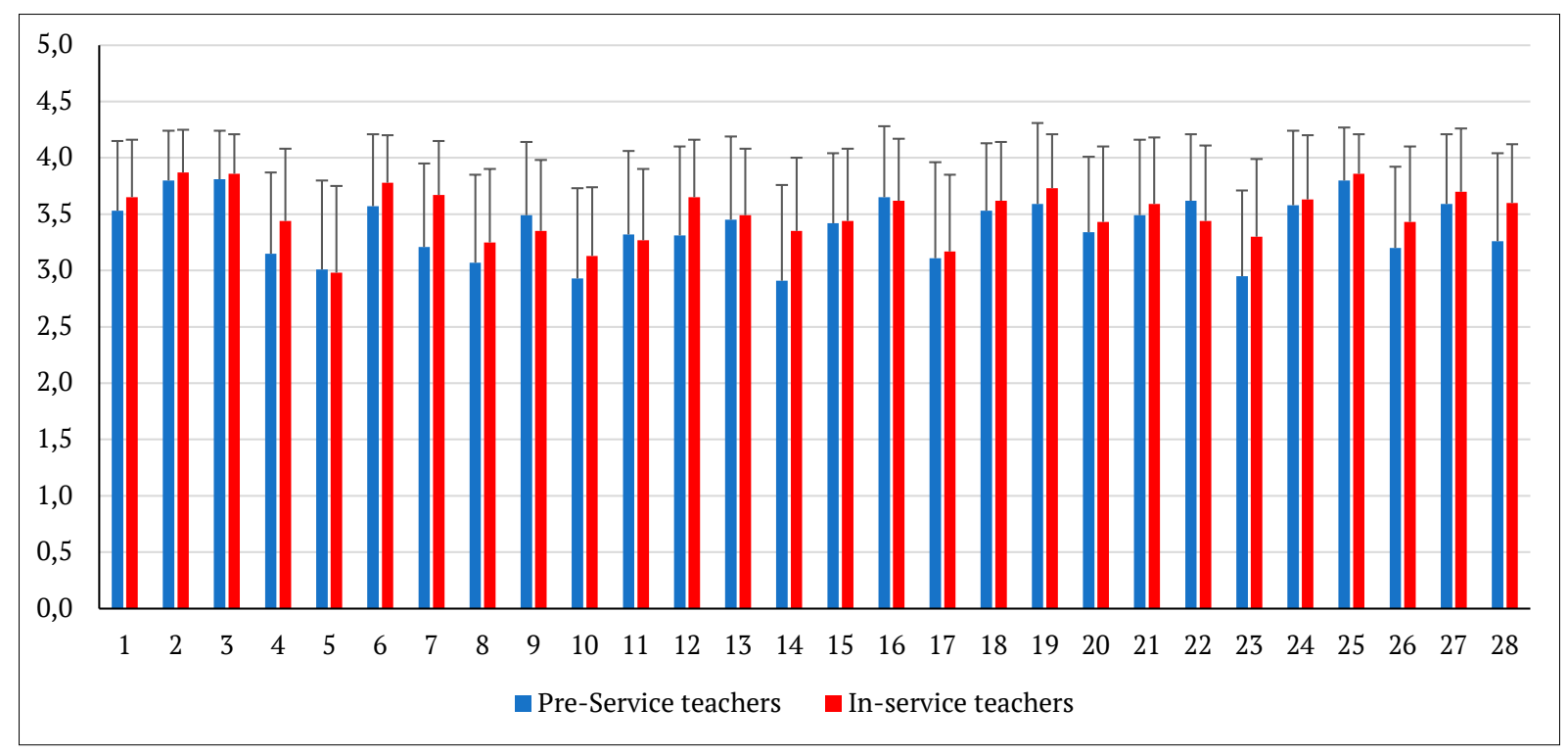

Figure 2

Means and Standard Deviations for Items 29-57

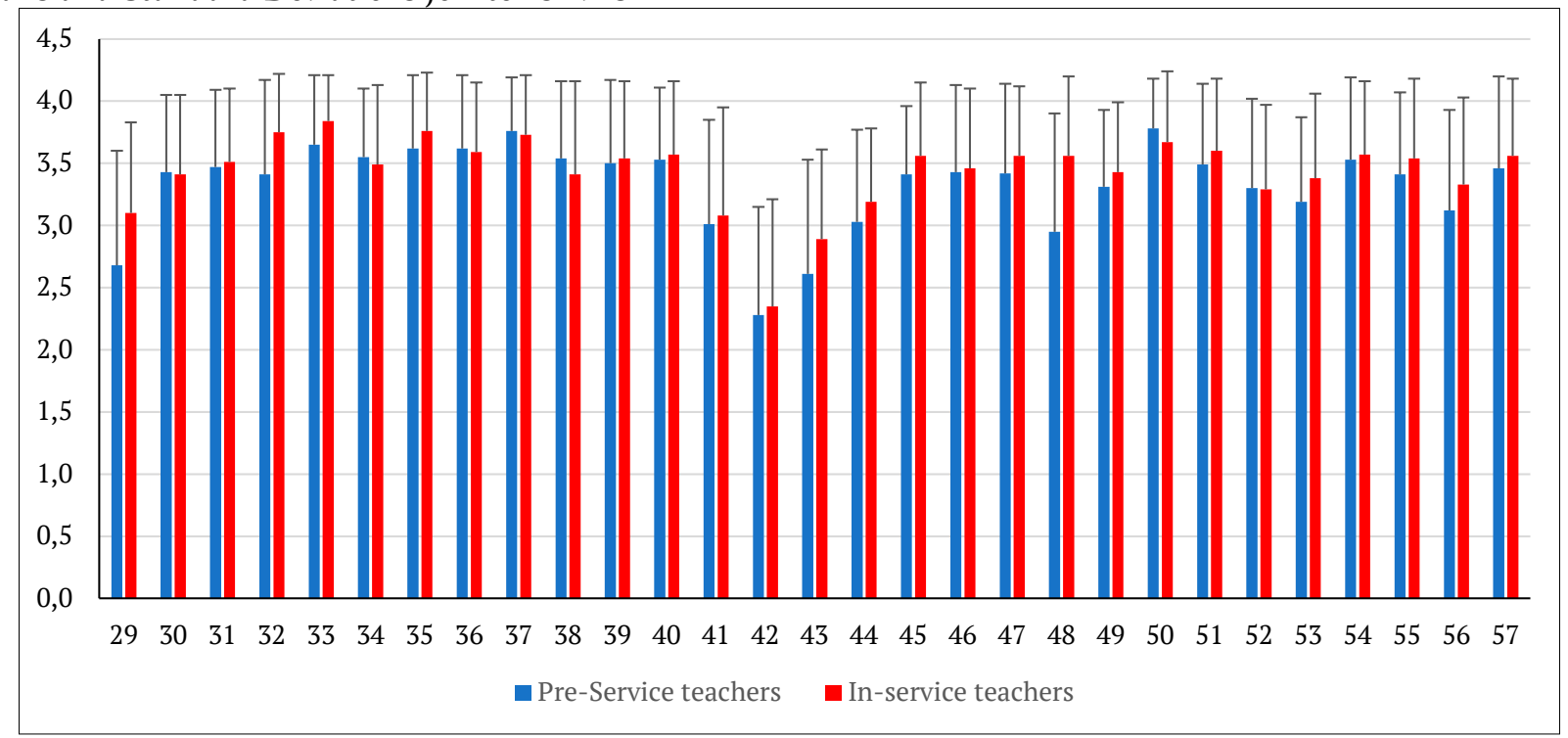


Table 3

Significantly Different Questionnaire Items $(p \leqslant 0.05)$

\begin{tabular}{|c|c|c|c|c|c|c|}
\hline \multirow{2}{*}{ No. } & \multirow{2}{*}{$\begin{array}{c}\text { Item } \\
\text { A good and effective EFL teacher is someone who should: }\end{array}$} & \multicolumn{2}{|c|}{ Pre-service Teachers } & \multicolumn{2}{|c|}{ In-service Teachers } & \multirow{2}{*}{ p value } \\
\hline & & Mean & SD & Mean & SD & \\
\hline 7. & Facilitate learners' responsibility and autonomy. & 3.24 & 0.74 & 3.67 & 0.48 & 0.00 \\
\hline 12. & $\begin{array}{l}\text { Establish clear classroom rules that everyone understands and } \\
\text { obeys. }\end{array}$ & 3.31 & 0.79 & 3.65 & 0.51 & 0.00 \\
\hline 14. & $\begin{array}{l}\text { Employ plenty of pair work and group work in which his/her } \\
\text { learners can practice English. }\end{array}$ & 2.91 & 0.85 & 3.35 & 0.65 & 0.00 \\
\hline 23. & $\begin{array}{l}\text { Support the notion that fluency is somewhat more important } \\
\text { than accuracy. }\end{array}$ & 2.95 & 0.76 & 3.30 & 0.69 & 0.00 \\
\hline 28. & Be flexible. & 3.26 & 0.78 & 3.60 & 0.52 & 0.00 \\
\hline 29. & Be neat and tidy in appearance. & 2.68 & 0.92 & 3.10 & 0.73 & 0.00 \\
\hline 32. & $\begin{array}{l}\text { Show interest in students (e.g. by remembering their names, etc.) } \\
\text { and their learning. }\end{array}$ & 3.41 & 0.76 & 3.75 & 0.47 & 0.00 \\
\hline 48. & $\begin{array}{l}\text { Vary class interaction strategies (e.g. use group and pair work, } \\
\text { drama, role-plays, debates, etc.). }\end{array}$ & 2.95 & 0.95 & 3.56 & 0.64 & 0.00 \\
\hline 4. & $\begin{array}{l}\text { Personalize his/her teaching to students' lives, needs, concerns, } \\
\text { goals, and interests. }\end{array}$ & 3.15 & 0.72 & 3.44 & 0.64 & 0.01 \\
\hline 6. & $\begin{array}{l}\text { Provide opportunities to use English through meaningful tasks } \\
\text { and activities. }\end{array}$ & 3.57 & 0.64 & 3.78 & 0.42 & 0.02 \\
\hline 33. & Have good communication skills. & 3.65 & 0.56 & 3.84 & 0.37 & 0.02 \\
\hline 43. & Be familiar with the social and cultural backgrounds of learners. & 2.61 & 0.92 & 2.89 & 0.72 & 0.05 \\
\hline
\end{tabular}

The pre-service teachers and in-service teachers held statistically significant opinions on 12 out of the 57 items (Table 3). It should be emphasized that the in-service teachers attached greater importance to all of the statistically significant items (items 4, 6, 7, 12, 14, 23, 28, 29, 32, 33, 43, and 48).

Six of the items $(4,6,7,14,23$, and 48$)$ can be directly related to actual teaching, arising out of the primary principles of CLT: "personalize his/her teaching to students' lives, needs, concerns, goals, and interests", "provide opportunities to use English through meaningful tasks and activities", "facilitate learners' responsibility and autonomy", "employ plenty of pair work and group work in which his/her learners can practice English", "support the notion that fluency is somewhat more important than accuracy", and "vary class interaction strategies (e.g. use group and pair work, drama, role-plays, debates, etc.)”.

Furthermore, the in-service teachers believed more strongly that they should set clear classroom rules, be flexible, be neat and tidy in appearance, show interest in students, have good communication skills, and be familiar with students' social and cultural backgrounds (items 12, 28, 29, 32, 33, and 43).

\section{Discussion}

Within the highest-mean items (Research question no. 1), six characteristics (items 2, 3, 25, 33, 35, and 37) were the same for both groups. The pre-service teachers added to the six qualities that the teacher ought to arouse their students' motivation, be helpful both inside and outside the classroom, build a positive relationship with students, and speak audibly and clearly. Most of these features refer to the nature of classroom relationships. In contrast, the in-service teachers, apart from showing interest in students, also added some features directly related to actual teaching: providing opportunities to practice English through meaningful activities, being creative and using various methods and techniques, and having both subject matter knowledge and pedagogical knowledge. This suggests that apart from being interested in their students, it is also the way 
the language is taught and what the professional background of a teacher is. The above-mentioned features represent (to a great deal) teachers' characteristics arising out of the principles of CLT. This might be considered a good sign due to the fact that traditional ways of teaching, along with teacher-centeredness, may still be prevalent in a number of countries worldwide, including Slovakia and the Czech Republic (Metruk, 2018).

Taking the lowest-mean items (Research question no. 2) into account, seven items (items 5, 10, 29, 41, 42, 43, and 44) were identified as the least important for both groups. Interestingly, the pre-service teachers' three lowest-mean items concerned CLT: employing plenty of pair work and group work activities, supporting the notion that fluency is somewhat more important than accuracy, and varying classroom interactional strategies. This indicates that the pre-service teachers may not prefer being taught with the use of some of the basic principles of CLT (pair work or group work, a greater focus on fluency, using more interaction strategies, etc.).

The in-service teachers' remaining three items included diagnosing learners' learning problems, being up-todate, and using as little L1 as possible. Being up-to-date and using the Internet and recent technologies in teaching can be regarded as a difficult and complex matter due to the fact that instructors do not generally seem to possess the required skills and are automatically expected to use the new affordances in order to facilitate the learning process (Metruk, 2020). Therefore, they sometimes seem reluctant to use new technologies and attach high importance to them. However, not using as little L1 as possible is not in line with one of the primary principles of CLT, and this finding somewhat supports the notion of traditional teaching approaches such as the grammar-translation method. On the whole, however, it can be concluded that the preservice teachers' and in-service teachers' opinions overlap when it comes to both the highest-mean items and the lowest-mean items in terms of the perception of a good and effective teacher.

As far as the differences between the pre-service teachers' and in-service teachers' perceptions of a good and effective teacher are concerned, apart from six items mostly related to the nature of classroom relationships (e.g. setting clear classroom rules, being neat and tidy in appearance, or being familiar with students' social and cultural backgrounds), six of the items with statistically significant differences were directly connected to CLT: personalizing teachers' teaching in accordance to students' lives, needs, or concerns; facilitating the responsibility and autonomy of learners; providing opportunities to use English through meaningful activities and tasks; employing plenty of pair work and group work activities; attaching a higher importance to fluency; and varying classroom interactional strategies. Thus, within this research question, the findings suggest that the pre-service teachers attached significantly lower importance to some typical characteristics of CLT in comparison to their in-service teacher counterparts. This research finding is in line with, for example, Brown's study (2009), but contradicts the study of Kourieos and Evripidou (2013), for instance, who indicate that the Cypriot learners wanted a learner-centered approach to a greater extent. The findings possibly indicate that EFL learners may still favor the traditional ways of teaching over CLT, where teachers represented the most important part of the teaching and learning process, employing the so-called teacher-centered approach. This may be a direct impact of this approach, which is still a dominant way of teaching in a number of countries across many school subjects.

All in all, taking into account the degree of differences between the pre-service teachers' and in-service teachers' perception, it can be concluded that the statistically significant differences were detected in only 12 instances out of the 57 items. Thus, it can be interpreted that no statistically significant differences were observed within the majority of items (79\%) and that the pre-service teachers and in-service teachers tended to disagree in only $21 \%$ of cases. Overall, general agreement exists on the qualities of a good and effective language teacher. Therefore, the findings of this study appear to corroborate the results of the studies conducted by Al-Mahrooqi, Denman, Al-Siyabi, and Al-Maamari (2015) as well as Shishavan, and Sadeghi (2009), but seem to be in contrast to studies carried out by Alimorad and Tajgozari (2016) and Park and Lee (2006).

\section{Conclusion}

This paper attempted to investigate the differences in pre-service teachers' and in-service teachers' perceptions of a good and effective language teacher. 
The research results indicate that six out of the ten highest-mean items (e.g. be able to present content in a meaningful way, be able to provide clear instructions for the task, or be fair and correct) and seven out of the ten lowest-mean items (e.g. give a reasonable amount of homework, have more than five years of teaching experience, or know English culture well) overlap. Some of the highest-mean items, however, differed. While the pre-service teachers included items related to the nature of classroom relationship (e.g. arouse students' motivation for learning English or build a positive relationship with students, but retaining a professional distance), the in-service teachers included some items directly related to actual teaching such as being creative, using various methods in teaching, or providing opportunities to use English through meaningful tasks and activities.

Taking the different lowest-mean items into consideration, the pre-service teachers assigned much less importance to employing plenty of pair work or group work activities or to supporting the notion that fluency is somewhat more important than accuracy, which somewhat suggests their preference for traditional teaching approaches. The in-service teachers' lowest-mean items included being up to date or use as little L1 as possible. Therefore, some differences can be observed in terms of the different items - pre-service teachers possibly preferring traditional teaching to some degree, while support for CLT was more prevalent in the in-service teacher group.

The third research question attempted to detect the actual differences in the perceptions of good and effective language teachers. It has been observed that the significant differences were perceived within the following 12 instances (in each of the 12 cases, the teacher group assigned higher importance to these statements).

A good and effective teacher should:

1. Personalize his/her teaching to students' lives, needs, concerns, goals, and interests.

2. Provide opportunities to use English through meaningful tasks and activities.

3. Facilitate learners' responsibility and autonomy.

4. Establish clear classroom rules that everyone understands and obeys.

5. Employ plenty of pair work and group work in which his/her learners can practice English.

6. Support the notion that fluency is somewhat more important than accuracy.

7. Be flexible.

8. Be neat and tidy in appearance.

9. Show interest in students (e.g. by remembering their names, etc.) and their learning.

10. Have good communication skills.

11. Be familiar with the social and cultural backgrounds of learners.

12. Vary class interaction strategies (e.g. use group and pair work, drama, role-plays, debates, etc.).

It should be mentioned that most of the statistically different items represent the basic principles of CLT; based on these findings, the pre-service teachers favored traditional teaching approaches more than their inservice counterparts. This may also provide some stimulus for university teachers regarding their EFL didactic courses, suggesting they pay more careful attention when introducing the fundamental principles of CLT and ensuring that their prospective teachers will follow those principles when they become actual teachers. They need to understand that omitting, for example, pair-work and group work activities ignores one of the fundamental principles of contemporary approaches to teaching. Moreover, the items that were statistically different such as personalizing his/her teaching to students' lives, needs, concerns, goals, and interests or facilitating learners' responsibility and autonomy should also be discussed in more detail during the preservice teachers university training so that these concepts, which are of major importance, are advocated later on when teaching at the lower-secondary or upper-secondary levels.

On the whole, however, it can be concluded that the pre-service teachers tended to generally agree with the inservice teachers on most of the items as only 12 out of the 57 items were significantly different. Thus, these findings support the results of other studies (e.g. Al-Mahrooqi, Denman, Al-Siyabi, \& Al-Maamari, 2015; Shishavan \& Sadeghi, 2009), but contradict the outcomes of other studies (Alimorad \& Tajgozari, 2016; Park \& Lee, 2006). 
In spite of some limitations, e.g. the pre-service teachers being from only one Slovak university or the size of both research sample groups, it is apparent that further investigation needs to be conducted in this field, especially in countries where such research has not been carried out to date. The differences in the perception of good and effective language teachers may negatively influence the teaching and learning process. Therefore, these discrepancies require the careful attention of teachers and researchers. Future research, based on these outcomes, and taking into consideration the limitations of this study ought to help provide greater clarity in this regard and shed more light on the differences between pre-service and in-service teachers' perceptions of effective language teaching.

\section{References}

Al-Mahrooqi, R., Denman, C., Al-Siyabi, J., \& Al-Maamari, F. (2015). Characteristics of a good EFL teacher: Omani EFL teacher and student perspectives. SAGE Open, 5(2). https://doi.org/10.1177/2158244015584782

Alimorad, Z., \& Tajgozari, M. (2016). A comparison of Iranian high school teachers' and students' perceptions of effective English teachers. SAGE Open, 6(4). https://doi.org/10.1177/2158244016679212

Alzobiani, I. (2020). The qualities of effective teachers as perceived by Saudi EFL students and teachers. English Language Teaching, 13(2), 32-47. https://doi.org/10.5539/elt.v13n2p32

Auerbach, C., \& Zeitlin, W. (2014). SSD for R: An R package for analyzing single-subject data. Oxford University Press.

Barnes, B., \& Lock, G. (2013). Student perceptions of effective foreign language teachers: A quantitative investigation from a Korean university. Australian Journal of Teacher Education, 38(2), 19-36. http://dx.doi. org/10.14221/ajte.2013v38n2.2

Brown, A. (2009). Students' and teachers' perceptions of effective foreign language teaching: A comparison of ideals. The Modern Language Journal, 93(1), 46-60. https://doi.org/10.1111/j.1540-4781.2009.00827.x

Çakmak, M., \& Gündüz, M. (2018). Pre-service ELT teachers' perceptions of characteristics of effective teachers. Gazi University Journal of Gazi Educational Faculty, 38(1), 359-383.

Çelik, S., Arikan, A., \& Caner, M. (2013). In the eyes of Turkish EFL learners: What makes an effective foreign language teacher? Porta Linguarum, 20, 287-297. https://doi.org/10.1186/s41239-019-0140-7

Delaney, J., Johnson, A., Johnson, T., \& Treslan, D. (2010). Students' perceptions of effective teaching in higher education[Project Report]. Memorial University of Newfoundland, St. John's, Newfoundland. https://research. library.mun.ca/8370/

Demiroz, H., \& Yesilyurt, S. (2015). Effective foreign language teaching: Perceptions of prospective English language teachers. Universal Journal of Educational Research, 3(11), 862-870. https://doi.org/10.13189/ ujer.2015.031112

Febriyanti, E. (2018). Investigating English department students' perceptions about a good English language teacher. International Journal of Language Education, 2(2), 83-95. https://doi.org/10.26858/ijole.v2i2.6378

Ghasemi, B., \& Hashemi, M. (2011). The study of the characteristics of successful English language teachers from the viewpoint of the English language students of Islamic Azad University, Hamedan Branch. Procedia - Social and Behavioral Sciences, 28, 411-415. https://doi.org/10.1016/j.sbspro.2011.11.078

Hojatpanah, S., \& Dashtestani, R. (2020). Electronic dictionaries as language learning tools for Iranian junior high school students. CALL-EJ - Computer-Assisted Language Learning Electronic Journal, 21(1), 79-96.

Hundarenko, O. (2019). Challenges of teaching academic writing skills in ESL classroom (Based on international teaching experience). Revista Romaneasca pentru Educatie Multidimensionala, 11(4), 70-83. https://doi. org/10.18662/rrem/158

Javid, C. (2014). Perceptive determination of Saudi EFL learners about the characteristics of an ideal English language teacher. Research on Humanities and Social Sciences, 4(8), 42-53.

Kapranov, O. (2020). In-service primary school teachers' account of phonetically difficult words in English as a foreign language. Research in Language, 17(3), 297-315. https://doi.org/10.2478/rela-2019-0018

Katooli, S., \& Abdolmanafi-Rokni, S. (2015). A comparative analysis of students' and teachers' perceptions of effective foreign language teaching in Iran. Journal of Applied Linguistics and Language Research Volume, 2(8), 57-75.

Kourieos, S., \& Evripidou, D. (2013). Students' perceptions of effective EFL teachers in university settings in Cyprus. English Language Teaching, 6(11), 1-16. http://dx.doi.org/10.5539/elt.v6n11p1

Lacková, M. (2019). Investigation of ESP vocabulary through corpus. Forlang. International Conference (pp. 88- 
93). Technical University of Košice.

Lee, J. (2010). The Uniqueness of EFL Teachers: Perceptions of Japanese Learners. TESOL Journal, 1(1), 23-48. https://doi.org/10.5054/tj.2010.214881

Leláková, E., \& Šavelová, N. (2020). Conjunctive adverbials used by Charlotte Brontë in the novel "Jane Eyre”. International Journal of English Linguistics, 10(3), 48-58. https://doi.org/10.5539/ijel.v10n3p48

Metruk, R. (2018). Researching speaking: Teaching and assessment. Palacký University Olomouc.

Metruk, R. (2020). Confronting the challenges of MALL: Distraction, cheating, and teacher readiness. International Journal of Emerging Technologies in Learning, 15(2), 4-14. https://doi.org/10.3991/ijet.v15i02.11325

Moradi, K., \& Sabeti, G. (2014). A comparison of EFL teachers and EFL students' understandings of 'highly effective teaching'. Procedia - Social and Behavioral Sciences, 98, 1204-1213. https://doi.org/10.1016/j. sbspro.2014.03.535

Mutlu, A., \& Özkan, Y. (2017). Pre-service English language teachers' views of the effective teacher and teaching. Mediterranean Journal of Humanities 7(1), 213-231. https://doi.org/10.13114/MJH.2017.332

Namaziandost, E., Neisi, L., Kheryadi, Nasri, M., \& Heidari-Shahreza, M. (2019). Enhancing oral proficiency through cooperative learning among intermediate EFL learners: English learning motivation in focus. Cogent Education, 6(1), 1683933. https://doi.org/10.1080/2331186X.2019.1683933

Namaziandost, E, Sabzevari, A., \& Hashemifardnia, A. (2018). The effect of cultural materials on listening comprehension among Iranian upper-intermediate EFL learners: In reference to gender. Cogent Education, 5(1), 1560601. https://doi.org/10.1080/2331186X.2018.1560601

Park, G., \& Lee, H. (2006). The characteristics of effective English teachers as perceived by high school teachers and students in Korea. Asia Pacific Education Review, 7, 236-248. https://doi.org/10.1007/BF03031547

Privitera, G., \& Ahlgrim-Delzell, L. (2019). Research methods for education. SAGE Publications, Inc.

Putrawan, G. (2019). A study on EFL learners' belief about translation as a learning strategy in Indonesia. Kervan - International Journal of Afro-Asiatic Studies, 23(1), 235-249. https://doi.org/10.13135/1825-263X/3318

Ramazani, M. (2014). Mismatches in beliefs between teachers and students, and characteristics of effective English teacher: An Iranian Context. Procedia - Social and Behavioral Sciences, 98, 1518-1527. https://doi. org/10.1016/j.sbspro.2014.03.573

Sabbah, S. (2018). Tertiary-level students' perceptions of the characteristics of effective English as a second language instructors. International Journal of English Language Teaching, 6(2), 1-24.

Sandholtz, J. (2011). Pre-service teachers' conceptions of effective and ineffective teaching practices. Teacher Education Quarterly, 38(3), 27-47.

Shishavan, H., \& Sadeghi, K. (2009). Characteristics of an effective english language teacher as perceived by Iranian teachers and learners of English. English Language Teaching, 2(4), 130-143.

Stognieva, O. (2019). Teaching business English with TED talks: Putting ideas into practice. Journal of Language and Education, 5(2), 95-111. https://doi.org/10.17323/jle.2019.7995

Stronge, J. (2018). Qualities of effective teachers ( $3^{\text {rd }}$ ed.). ASCD.

Todaka, Y. (2020). Extensive listening with instruction in how to help Japanese EFL learners improve English listening skills. Academic Journal of International Education Research, 1(1), 29-34. https://doi.org/10.5281/ zenodo. 321540

Tok, H. (2010). Comparing teachers' and students' perceptions of effective foreign language teaching. A case study in Turkey. International Conference on New Trends in Education and Their Implications (pp. 405-413). ICONTE.

Zadeh, R. (2016). EFL learners' attitudes and perceptions about an effective English language teacher. Journal of Applied Linguistics and Language Research, 3(2), 148-156.

Zhang, O., \& Watkins, D. (2007). Conceptions of a good tertiary EFL teacher in China. TESOL Quarterly, 41(4), 781-790. https://doi.org/10.1002/j.1545-7249.2007.tb00103.x 
APPENDIX A

\section{Students' and teachers' means and standard deviations - all items}

\begin{tabular}{|c|c|c|c|c|c|c|}
\hline \multirow{2}{*}{ No } & \multirow{2}{*}{$\begin{array}{c}\text { Item } \\
\text { A good and effective EFL teacher is someone who should: }\end{array}$} & \multicolumn{2}{|c|}{ Students } & \multicolumn{2}{|c|}{ Teachers } & \multirow{2}{*}{$\begin{array}{c}\mathbf{p} \\
\text { value }\end{array}$} \\
\hline & & Mean & SD & Mean & SD & \\
\hline 1. & Be well prepared for each lesson. & 3.53 & 0.62 & 3.65 & 0.51 & 0.20 \\
\hline 2. & Be able to provide clear instructions for tasks. & 3.8 & 0.44 & 3.87 & 0.38 & 0.28 \\
\hline 3. & Be able to present content to students in a meaningful way. & 3.81 & 0.43 & 3.86 & 0.35 & 0.49 \\
\hline 4. & Personalize his/her teaching to students' lives, needs, concerns, goals, and interests. & 3.15 & 0.72 & 3.44 & 0.64 & 0.01 \\
\hline 5. & Give a reasonable amount of homework/home assignments. & 3.01 & 0.79 & 2.98 & 0.77 & 0.83 \\
\hline 6. & Provide opportunities to use English through meaningful tasks and activities. & 3.57 & 0.64 & 3.78 & 0.42 & 0.02 \\
\hline 7. & Facilitate learners' responsibility and autonomy. & 3.24 & 0.74 & 3.67 & 0.48 & 0.00 \\
\hline 8. & Be up-to-date (e.g. use the Internet and recent technologies in teaching). & 3.07 & 0.78 & 3.25 & 0.65 & 0.13 \\
\hline 9. & Make learning fun. & 3.49 & 0.65 & 3.35 & 0.63 & 0.21 \\
\hline 10. & Know English culture well. & 2.93 & 0.80 & 3.13 & 0.61 & 0.11 \\
\hline 11. & Teach English in English - use as little L1 (mother tongue) as possible. & 3.32 & 0.74 & 3.27 & 0.63 & 0.64 \\
\hline 12. & Establish clear classroom rules that everyone understands and obeys. & 3.31 & 0.79 & 3.65 & 0.51 & 0.00 \\
\hline 13. & Be upbeat (positive and enthusiastic; making you feel that the future will be good). & 3.45 & 0.74 & 3.49 & 0.59 & 0.69 \\
\hline 14. & $\begin{array}{l}\text { Employ plenty of pair work and group work in which his/her learners can practice } \\
\text { English. }\end{array}$ & 2.91 & 0.85 & 3.35 & 0.65 & 0.00 \\
\hline 15. & $\begin{array}{l}\text { Teach how to learn English outside the classroom (teach language learning } \\
\text { strategies). }\end{array}$ & 3.42 & 0.62 & 3.44 & 0.64 & 0.81 \\
\hline 16. & Arouse students' motivation for learning English. & 3.65 & 0.63 & 3.62 & 0.55 & 0.77 \\
\hline 17. & Diagnose learners' learning problems. & 3.11 & 0.85 & 3.17 & 0.68 & 0.61 \\
\hline 18. & Manage the class time well and use the time efficiently. & 3.53 & 0.60 & 3.62 & 0.52 & 0.34 \\
\hline 19. & Be creative; use various methods and techniques in teaching. & 3.59 & 0.72 & 3.73 & 0.48 & 0.19 \\
\hline 20. & Teach English adapted to students' English proficiency levels. & 3.34 & 0.67 & 3.43 & 0.67 & 0.43 \\
\hline 21. & Actively listen to students' opinions and let them express themselves. & 3.49 & 0.67 & 3.59 & 0.59 & 0.35 \\
\hline 22. & Be helpful to students inside and outside the classroom. & 3.62 & 0.59 & 3.44 & 0.67 & 0.10 \\
\hline 23. & Support the notion that fluency is somewhat more important than accuracy. & 2.95 & 0.76 & 3.30 & 0.69 & 0.00 \\
\hline 24. & Help students develop self-confidence in order to learn English well. & 3.58 & 0.66 & 3.63 & 0.58 & 0.61 \\
\hline 25. & Be fair and correct (with feedback, giving turns, attending to individual differences). & 3.80 & 0.47 & 3.86 & 0.35 & 0.40 \\
\hline 26. & Be disciplined and punctual. & 3.20 & 0.72 & 3.43 & 0.67 & 0.06 \\
\hline 27. & $\begin{array}{l}\text { Be knowledgeable (have both subject matter knowledge and pedagogical } \\
\text { knowledge). }\end{array}$ & 3.59 & 0.62 & 3.70 & 0.56 & 0.3 \\
\hline 28. & Be flexible. & 3.26 & 0.78 & 3.60 & 0.52 & 0.00 \\
\hline 29. & Be neat and tidy in appearance. & 2.68 & 0.92 & 3.10 & 0.73 & 0.00 \\
\hline 30. & Be available for students. & 3.43 & 0.62 & 3.41 & 0.64 & 0.86 \\
\hline 31. & Be open to constructive criticism. & 3.47 & 0.62 & 3.51 & 0.59 & 0.74 \\
\hline 32. & Show interest in students (e.g. by remembering their names, etc.) and their learning. & 3.41 & 0.76 & 3.75 & 0.47 & 0.00 \\
\hline 33. & Have good communication skills. & 3.65 & 0.56 & 3.84 & 0.37 & 0.02 \\
\hline 34. & Have a high level of English proficiency. & 3.55 & 0.55 & 3.49 & 0.64 & 0.55 \\
\hline 35. & Be patient (allow for students' questions, comments, and participation). & 3.62 & 0.59 & 3.76 & 0.47 & 0.12 \\
\hline 36. & $\begin{array}{l}\text { Build a positive relationship with students but focus on retaining a professional } \\
\text { distance. }\end{array}$ & 3.62 & 0.59 & 3.59 & 0.56 & 0.73 \\
\hline 37. & Be polite and respect the personality of students. & 3.76 & 0.43 & 3.73 & 0.48 & 0.74 \\
\hline 38. & Not lose his/her temper and get angry. & 3.54 & 0.62 & 3.41 & 0.75 & 0.29 \\
\hline
\end{tabular}




\section{QUALITIES OF A GOOD AND EFFECTIVE TEACHER}

39. Establish a relaxed atmosphere in the classroom.

$\begin{array}{lllll}3.50 & 0.67 & 3.54 & 0.62 & 0.72\end{array}$

40. Monitor progress and provide learners with useful and constructive feedback.

$\begin{array}{lllll}3.53 & 0.58 & 3.57 & 0.59 & 0.66\end{array}$

41. Have a university degree in Teaching English as a Foreign Language.

$\begin{array}{lllll}3.01 & 0.84 & 3.08 & 0.87 & 0.65\end{array}$

42. Have more than five years of experience teaching English.

$\begin{array}{lllll}2.28 & 0.87 & 2.35 & 0.86 & 0.66\end{array}$

43. Be familiar with the social and cultural backgrounds of learners.

$\begin{array}{lllll}2.61 & 0.92 & 2.89 & 0.72 & 0.05\end{array}$

44. Be aware of the current teaching techniques.

$\begin{array}{lllll}3.03 & 0.74 & 3.19 & 0.59 & 0.15\end{array}$

45. Know how to assess learners' performance reasonably, correctly, and fairly.

$\begin{array}{lllll}3.41 & 0.55 & 3.56 & 0.59 & 0.13\end{array}$

46. Regard errors as an inseparable part of the learning process; self-correction is encouraged.

47. Have good and effective classroom management skills.

$\begin{array}{lllll}3.42 & 0.72 & 3.56 & 0.56 & 0.22\end{array}$

48. Vary class interaction strategies (e.g. use group and pair work, drama, role-plays,

49. Be able to assess learners' strengths and weaknesses.

50. Speak audibly and clearly.

51. Be able to explain unfamiliar concepts in various ways.

$\begin{array}{lllll}3.49 & 0.65 & 3.60 & 0.58 & 0.27\end{array}$

52. Come to class on time and finish on time.

53. Be able to cooperate with colleagues to improve the current teaching practices.

54. Be confident and have self-control.

55. Have a positive attitude towards change and innovation.

56. Participate in teacher professional growth events such as seminars, workshops, conferences, etc. in order to develop professionally. 